Thorax (1949), 4, 101.

\title{
STERILE SEROUS EFFUSIONS IN CASES OF LOBAR PNEUMONIA TREATED WITH SULPHONAMIDES
}

\author{
BY \\ R. C. NAIRN \\ From the Department of Pathology, Liverpool University
}

In about one-tenth of cases of lobar pneumonia treated with sulphonamides, a serous pleural effusion develops a week or two after the onset of the pneumonia. Such effusions have been discussed by Burford and Blades (1942), Morgan and Wylie-Smith (1943), and Conybeare (1946). Serous pleural effusions may -also occur in cases of tuberculosis, intrathoracic carcinoma, congestive cardiac failure, nephritis, rheumatic fever (Hangarter, 1944), and atypical pneumonia (Turner, 1945), to name the commonest causes. Differential diagnosis of postpneumonic cases from these other conditions is difficult, especially when a patient has had chemotherapy at home for a suspected pneumonia and is admitted to hospital after the effusion has developed. The purpose of the present paper is to assess the value of the usual investigations in establishing the aetiology of the effusion.

\section{Present Investigation}

Ten patients who after treatment with sulphonamides for lobar pneumonia developed a serous pleural effusion .were investigated both clinically and pathologically, and compared with 21 cases of tuberculous pleural effusion, nine cases of pleural effusion associated with intrathoracic carcinoma, and 10 indeterminate cases of serous pleural effusion.

In the named groups, only cases in which the diagnosis was well established were considered. The criteria for diagnosing an effusion as postpneumonic were indisputable clinical and radiological evidence of previous lobar pneumonia (five cases), later development of a pneumococcal empyema (three cases), or demonstration of the causative pathology at autopsy (two cases). In the tuberculous effusions, only cases in which the tubercle bacillus was demonstrated either directly or by guinea-pig inoculation are included. The cases of intrathoracic carcinoma were all proved at subsequent autopsy. The ten cases of the indeterminate group failed to satisfy any of the above criteria ; on clinical grounds four of these were probably pneumonic and six tuberculous.

To assess the value of clinical findings and laboratory investigations in differential diagnosis the following data were employed:

Clinical.-Duration of illness before the effusion was first demonstrated ; mode of onset of symptoms; and response of the initial illness to sulphonamides where these were used.

Pathological.-Naked eye appearance of the fluid ; total and differential cell counts ; sodium chloride estimations; and bacteriological investigation. Erythrocyte sedimentation rates were also measured in most of the patients.

\section{Laboratory Procedure}

As far as possible routine laboratory methods only were employed.

About $30 \mathrm{ml}$. of pleural fluid were collected in each case with aseptic precautions and immediately divided into three portions as follows.

1 To a tube containing $20 \mathrm{mg}$. of potassium oxalate to prevent coagulation $10 \mathrm{ml}$. were transferred. Samples of this were taken, after thorough mixing, for total and differential cell counts. Counting was carried out directly or after diluting the specimen with normal saline in a Fuchs-Rosenthal counting chamber, using $1 \%$ brilliant cresyl blue in saline to differentiate the nucleated cells. The remainder of this specimen was centrifuged and smears of the deposit were stained with Leishman's stain to confirm the differential counts obtained from the wet preparation. These examinations were carried out within an hour of thoracentesis. Because potassium oxalate causes slight shrinkage and deformation of cells and precipitation of calcium oxalate, control cell counts were performed on unclotted specimens. Comparison showed that the method chosen was quite adequate for broad differentiation of the preponderant cell types.

2. About $10 \mathrm{ml}$. were kept for observation and chloride estimations.

3. The remainder was transferred to a sterile tube for bacteriological investigation. Blood-agar plates and nutrient broth (para-aminobenzoic acid being 
used where sulphonamides had been recently administered) were inoculated with material from the centrifuged deposit of this sample and the rest of the deposit was used for making smears which were stained by Gram's and Ziehl-Neelson's methods.

Fluid for guinea-pig inoculation was usually taken at a later date.

\section{RESULTS}

Clinical Investigation.-This was almost without exception a good diagnostic guide (Table I).

TABLE I

Duration of Previous Illness

\begin{tabular}{l|c|c|c|c|c}
\hline & \multicolumn{2}{|c|}{ Duration of Previous Illness } & Total \\
\cline { 2 - 3 } & $\begin{array}{c}\text { Under } \\
2 \\
\text { Weeks }\end{array}$ & $\begin{array}{c}2-3 \\
\text { Weeks }\end{array}$ & $\begin{array}{c}3-4 \\
\text { Weeks }\end{array}$ & $\begin{array}{c}\text { Over } \\
4 \\
\text { Weeks }\end{array}$ & $\begin{array}{c}\text { No. } \\
\text { of } \\
\text { Cases }\end{array}$ \\
\hline $\begin{array}{l}\text { Lobar pneu- } \\
\text { monia) . }\end{array}$ & 6 & 3 & 1 & 0 & 10 \\
Tuberculosis & 2 & 4 & 6 & 9 & 21 \\
Carcinoma . & 0 & 0 & 1 & $8^{*}$ & 9 \\
Indeterminate & 2 & 3 & 1 & 4 & 10 \\
\hline
\end{tabular}

* The majority of these were over 2 months.
Seven of the post-pneumonic cases and none of the others gave a clear history of a recent acute pyrexial illness of sudden onset, readily recognizable as lobar pneumonia. In the indeterminate group, of the four cases probably pneumonic in origin, two had been ill for less than two weeks and two for less than three weeks.

Nine of the post-pneumonic cases had a history of initial improvement when sulphonamides were given. Such improvement was much rarer and less definite in the other groups.

All the post-pneumonic effusions in this series occurred after the end of the first week of illness.

Pathological Investigations.-In no case did simple immediate pathological investigations suggest a diagnosis of post-pneumonic effusion. The inconclusiveness of the usual investigations is illustrated by Table II, which shows clearly that macroscopic appearance, coagulum production, total and differential cell counts throw no light on the aetiology.

No cytological finding could be regarded as specific; the cytological picture of the fluid from any one disease invariably had its counterpart in each of the others.

TABLE II

Simple ANALYsis of EfFusions

\begin{tabular}{|c|c|c|c|c|c|}
\hline \multicolumn{2}{|c|}{ Properties of Pleural Effusion } & \multirow{2}{*}{$\begin{array}{c}\begin{array}{c}\text { Lobar } \\
\text { Pneumonia } \\
\text { (10 cases) }\end{array} \\
2\end{array}$} & \multirow{2}{*}{$\frac{\begin{array}{c}\text { Tuberculosis } \\
\text { (21 cases) }\end{array}}{6}$} & \multirow{2}{*}{$\frac{\begin{array}{c}\text { Carcinoma } \\
(9 \text { cases })\end{array}}{3}$} & \multirow{2}{*}{$\frac{\begin{array}{c}\text { Indeterminate } \\
(10 \text { cases })\end{array}}{3}$} \\
\hline Macroscopic appearance & Clear & & & & \\
\hline & Opalescent $\ldots$ & 7 & 13 & 3 & 6 \\
\hline & Blood-stained & 1 & 2 & 3 & 1 \\
\hline \multirow{3}{*}{$\begin{array}{l}\text { Production of a coagulum } \\
\text { on standing }\end{array}$} & . $\quad$. & 1 & 3 & 1 & 3 \\
\hline & $\begin{array}{ll}\ldots & .\end{array}$ & 8 & 14 & 5 & 2 \\
\hline & $\begin{array}{lll}\text { Massive } & \ldots & \ldots\end{array}$ & 1 & 4 & 3 & 4 not recorded \\
\hline \multirow[t]{3}{*}{ Total cell count } & $\begin{array}{ccc}\text { Less than } & 2,000 & \text { per } \\
\text { c.mm. } & . & .\end{array}$ & 2 & 5 & 3 & 2 \\
\hline & 2,000-5,000 per c.mm. & 6 & 12 & 5 & 7 \\
\hline & $\begin{array}{ccc}\text { More than } 5,000 & \text { per } \\
\text { c.mm. } & \cdots & . \\
\end{array}$ & 2 & 4 & 1 & 1 \\
\hline \multirow[t]{3}{*}{ Differential count } & Mainly lymphocytes & 6 & 15 & 6 & 7 \\
\hline & Mainly neutrophils .. & 2 & 2 & 1 & 1 \\
\hline & $\begin{array}{ccc}\text { Mainly } & \text { endothelial } \\
\text { cells } & . . & . .\end{array}$ & 2 & 4 & 2 & 2 \\
\hline
\end{tabular}


Other investigations, apart from the search for tubercle bacilli, were similarly lacking in value.

The sodium chloride content of 28 of the fluids, eight pneumonic, 14 tuberculous, and six malignant, was determined (Table III).

TABLE III

Sodium ChLORIDE CONTENT OF EFfusion

\begin{tabular}{l|c|c|c|c}
\hline & $\begin{array}{c}\text { Lobar } \\
\text { Pneu- } \\
\text { monia }\end{array}$ & $\begin{array}{c}\text { Tuber- } \\
\text { culosis }\end{array}$ & $\begin{array}{c}\text { Car- } \\
\text { cinoma }\end{array}$ & $\begin{array}{c}\text { All } \\
\text { Cases }\end{array}$ \\
\hline $\begin{array}{l}\text { No. of case : exam- } \\
\text { ined } \ldots\end{array}$ & 8 & 14 & 6 & 28 \\
\hline $\begin{array}{l}\text { Range of values } \\
\text { in mg./100 ml. } \\
\text { fluid } \ldots\end{array}$ & $548-648$ & $551-642$ & $528-636$ & $528-648$ \\
\hline Arithmetical mean & 594 & 600 & 582 & 594 \\
\hline
\end{tabular}

Each type of effusion had the same even distribution through the range of values and there was no hint of correlation with aetiology.

Gram stains were unrewarding in all cases. An occasional Gram-positive coccus was seen, presumably a contaminant ; its presence was unrelated to the aetiology of the effusion.

Ziehl-Neelson staining revealed tubercle bacilli in two of the cases of tuberculous effusion, and guinea-pig inoculation was positive in the rest of the cases classed as tuberculous.

Culture revealed only Staphylococcus albus in $16 \%$ of cases, and there was no correlation with aetiology. Pneumococci were grown in one case of carcinoma.

Erythrocyte sediment rates (Wintrobe technique) in seven post-pneumonic, 20 tuberculous, and five malignant cases of effusion had no differential diagnostic value (Table IV).

TABLE IV

SEDIMENTATION RATES (Wintrobe)

\begin{tabular}{c|c|c|c|c}
\hline & $\begin{array}{c}\text { Lobar } \\
\text { Pneu- } \\
\text { monia }\end{array}$ & $\begin{array}{c}\text { Tuber- } \\
\text { culosis }\end{array}$ & $\begin{array}{c}\text { Car- } \\
\text { cinoma }\end{array}$ & $\begin{array}{c}\text { All } \\
\text { Cases }\end{array}$ \\
\hline $\begin{array}{c}\text { No. of cases exam- } \\
\text { ined .. .. }\end{array}$ & 7 & 20 & 5 & 32 \\
\hline $\begin{array}{c}\text { Range of values } \\
\text { in mm. in 1 hour }\end{array}$ & $4-52$ & $1-60$ & $2-40$ & $1-60$ \\
\hline Arithmetical mean & 19 & 21 & 14 & 20 \\
\hline
\end{tabular}

\section{Discussion}

The present investigation suggests that simple analysis of the fluid is of no assistance in the differential diagnosis of serous effusions.

Cytology is of value only in excluding empyema. The diagnostic significance of the cytological formulae of effusions was first stressed by Widal and Ravaut (1900), who stated that a lymphocytic exudate was characteristic of tuberculosis, a polymorphonuclear exudate suggested acute infections, and an exudate consisting predominantly of endothelial cells was mechanical in origin. Since this time many workers have questioned the value of "cytodiagnosis." Miller (1904) from an investigation of 75 ascitic and pleural fluids concluded that a study of the cells was of little diagnostic value. Sahli (1911) postulated certain general principles of cytology, claiming that " in each concrete case we must assume a critical attitude toward the various findings obtained by this method of examination and place but little confidence in any set of 'cytodiagnostic formulae' . . . there is not a single cytologic picture of these fluids that can be regarded as pathognomonic for any one type of disease." More recent attempts at cytological study by special techniques have been made by Scott and Finland (1934) and Castaigne and Laur (1945), using supravital staining. The former workers were able to show that in uninfected effusions occurring in cases of pneumonia receiving only general or serum treatment, $80-100 \%$ of the cells were polymorphonuclears during the first week, the proportion falling below $60 \%$ after the eighth day; a lymphocytosis was the rule after the crisis. The latter workers emphasize that while supravital techniques allow some correlation of cytology with age and activity of the disease process, routine methods of cytodiagnosis give only a non-specific picture. Despite these and other studies (Foord, Youngberg, and Wetmore, 1929 ; Pinner and Moerke, 1930; Phillips and McDonald, 1948) the importance of the differential cell count is still greatly stressed by many.

The commonest finding in all types of serous effusion in the present study was a lymphocytosis. This was also the experience of Phillips and McDonald (1948). The post-pneumonic effusions dealt with in this investigation were examined at a stage similar to the post-crisis stage of Scott and Finland (1934), and the findings are comparable. Since the advent of chemotherapy very few effusions are nowadays examined at an earlier stage, and there are no recorded data to compare with the findings of Scott and Finland in fluids 
examined before the pneumonia had reached its crisis.

It is still frequently maintained that neutrophil preponderance in the type of effusion under discussion is quite characteristic of a pneumonic aetio$\log$ : this opinion is not supported by the present study, in which a neutrophilia also occurred in two out of 31 tuberculous effusions. Similarly, Feldman and Lewis (1946) found a neutrophil preponderance in four out of 57 tuberculous fluids examined. These workers reported that subsequent examinations showed an eventual change to lymphocyte preponderance. In the few serial examinations carried out in the present series, the only notable changes in cytology observed were in the three cases of post-pneumonic effusion which later developed empyema, and these did not show an excess of neutrophils until some weeks after the effusion was first demonstrated.

The chloride content of the fluids is likewise of no diagnostic significance. The absence of correlation with aetiology in the present series is in accord with analyses by Riska (1945) of 43 cases of serous pleural effusion which included four cases of post-pneumonic effusion. Vannfält (1944) carried out sodium chloride estimations on 75 specimens of tuberculous pleural fluid, obtaining a mean value of $580 \mathrm{mg}$. per $100 \mathrm{ml}$. and a range comparable with the present series: he found no correlation between the chloride content of the fluid and either the patient's clinical condition, or his progress, or the pathological findings in the fluid.

The microscopic search for tubercle bacilli gives positive results in a very small percentage of cases of pleural effusion ; it provides, however, the only evidence of value to be obtained from immediate examination of the specimens. Culture and guineapig inoculation for the tubercle bacillus, though essential investigations, are not of immediate assistance.

Cytological diagnosis of malignant disease, either by film or sectioning of centrifuged deposits, is a very uncertain procedure, though occasionally valuable.

Erythrocyte sedimentation rates were unhelpful in the present series, but Hangarter (1944) has pointed out that they are highly significant in differentiating the effusions of rheumatic fever: he states that in the early stages in such cases, values between 60 and $100 \mathrm{~mm}$. in the first hour (tech- nique unstated, presumably Westergren) are the rule.

The value of clinical data which Trail (1943), Hangarter (1944), Conybeare (1946), and many others have emphasized is well attested by the present series. An investigation into 59 cases of tuberculous effusion by Feldman and Lewis (1946) also bears out this conclusion: they describe nine acute cases which might be confused with pneumonia, but point out that fluid was probably present from the onset and that the initial illness did not respond to chemotherapy.

\section{SUMMARY}

Ten cases of non-purulent pleural effusion occurring in sulphonamide-treated lobar pneumonia were compared clinically and pathologically with 21 cases of tuberculous effusion, nine cases of malignant effusion, and 10 indeterminate cases of serous pleural effusion. Clinical data provided good differential criteria; immediate laboratory investigations were of little value.

I wish to thank Professor H. L. Sheehan for his advice and criticism, and Dr. J. J. Rivlin for carrying out certain control investigations.

\section{REFERENCES}

Burford, T. H., and Blades, B. (1942). J. Amer. med. Ass., 118, 950.

Castaigne, P., and Laur, C. M. (1945). Bull. Soc. méd. Hôp. Paris, 61, 159.

Conybeare, J. J. (1946). Guy's Hosp. Gaz., 60, 136.

Feldman, D. J., and Lewis, H. P. (1946). Med. Clin. N. Amer., 30, 245.

Foord, A. G., Youngberg, G. E., and Wetmore, V. (1929). J. Lab. clin. Med., 14, 417.

Hangarter (1944). Dtsch. med. Wschr., 70, 326.

Miller, J. L. (1904). Amer. Med., 8, 835.

Morgan, T. N., and Wylie-Smith, R. (1943). Lancet, 2 , 731 .

Phillips, S. K., and McDonald, J. R. (1948). Amer. J. med. Sci., 216, 121.

Pinner, M., and Moerke, G. (1930). Amer. Rev. Tuberc., 22,121 .

Riska, N. (1945). Nord. Med., 27, 1897.

Sahli, H. (1911). A Treatise on Diagnostic Methods of Examination. Edited by N. B. Potter. Philadelphia and London, W. B. Saunders Co. 2nd Edition, p. 918.

Scott, T. F. M., and Finland, M. (1934). Amer. J. med. $S c i ., 188,322$.

Trail, R. R. (1943). Brit. med. J., $1,98$.

Turner, R. W. D. (1945). Lancet, 1, 493.

Vannfält, K. A. (1944). Uppsala Läk Fören. Förh., 49, 249

Widal, F., and Ravaut (1900). C.R. Soc. Biol., Paris, 52, 648. 